\title{
Best Management Practices (BMPs) for Nitrogen Fertilizer in Forage Grasses
}

\author{
Ademar Pereira Serra, Marlene Estevão Marchetti, \\ Elisângela Dupas, Simone Candido Ensinas, \\ Elaine Reis Pinheiro Lourente, \\ Eulene Francisco da Silva, \\ Roberto Giolo de Almeida, \\ Carla Eloize Carducci and \\ Alessandra Mayumi Tokura Alovisi
}

Additional information is available at the end of the chapter

http://dx.doi.org/10.5772/intechopen.70345

\begin{abstract}
There is a concern about the growing population and limitation in natural resources which are taking the population to direct its agricultural systems into a more productive and efficient activity, looking to avoid a negative impact on the surrounding environment. The industry energy expended to produce nitrogen $(\mathrm{N})$-fertilizer is considered an indirect consumption of energy in agriculture, which is higher with an increasing forage yield. Nitrogen is the key nutrient associated with high-yielding production in forage grass and grain crops. The aim of this chapter is to introduce the best management practices (BMPs) for $\mathrm{N}$-fertilizer application in forage grasses to improve $\mathrm{N}$-use efficiency, since the most economical way to feed livestock is forage plants where its potential biomass production is not well explored. The BMPs basically follow three management practices: (1) soil nutrient availability and forage requirement, (2) fertilizer application, and (3) decrease in nutrient losses from soil. In order to take a decision on applying $\mathrm{N}$-fertilizer to accomplish forage grasses production with social, economic, and environmental benefits, the $\mathrm{N}$-fertilizer use in forage grasses is going to follow the "Right rate, Right source, Right place, and Right time (4R) nutrient stewardship." The application of the $4 R^{\prime}$ s nutrients stewardship is directly associated with economic, social, and environmental impact. The capacity of the $4 R^{\prime}$ s implementation worldwide turns into a best guide to improve the striving of better $\mathrm{N}$-use efficiency in forage grass. The $4 \mathrm{R}^{\prime} \mathrm{s}$ are interrelated; thus, the recommendation of $\mathrm{N}$-fertilizer rates cannot be prescribed without the combination of the $4 R^{\prime} \mathrm{s}$ where a whole system to be followed should be considered to decide about $\mathrm{N}$-fertilizer in pasture. Consequently, any decision in one of the $4 \mathrm{R}^{\prime} \mathrm{s}$ is going to affect the expected $\mathrm{N}$-fertilizer results and dry matter production.
\end{abstract}


Keywords: soil fertility, N-fertilizer recovery, N-use efficiency, Brachiaria spp., Panicum maximum

\section{Introduction}

A remarkable increase in cattle herd in Brazil occurred from 1977 to 2012, with the Midwest region showing a high increase [1]. However, extending to new frontiers for Brazilian cattle herd is constraint to limited areas and consequently the yield of forage grass needs to be increased. Thus, the intensification of livestock production tends to intensive management. Increasing livestock production due to the world demand for meat is quite associated with an improvement in forage production. To feed grazed animal in livestock, tropical forages are the cheapest source of food in Brazil. Brachiaria spp., Panicum maximum, and Stylosanthes spp. are the majorly cultivated forage in Brazil. Among the gender Brachiaria spp., B. brizantha cv. Marandu is majorly cultivated in Brazil with $45 \%$ of the whole area with cultivated pastures [2], which correspond to approximately 45 million hectares. However, in Brazil there are millions of hectares with degraded pastures, due to soil with low fertility and no replacement of nutrients removed from soil over the years.

The uses of synthetic fertilizers in agriculture are primordial to sustain the growing population worldwide, which tends to increase linearly with population growth at least until 2050 [3]. Different from phosphorus (P), potassium (K), calcium (Ca), magnesium (Mg), and micronutrients [boron $(\mathrm{B})$, zinc $(\mathrm{Zn})$, iron $(\mathrm{Fe})$, manganese $(\mathrm{Mn})$, and copper $(\mathrm{Cu})$ ], N needs to be applied to every cropping season, because $\mathrm{N}$ does not remain longer in soil profile. Soil organic matter (SOM) is the main source of $\mathrm{N}$, which can compile $95 \%$ of the total $\mathrm{N}$ and $5 \%$ remain as $\mathrm{NO}_{3}-\mathrm{N}$ and $\mathrm{NH}_{4}-\mathrm{N}$. However, the amount of $\mathrm{N}$ in soil varies a lot due to many factors including soil clay content, moisture, aeration, temperature, tillage, rainfall, and so on, which implies a high $\mathrm{N}$ dynamic in soil and consequently the problem in measuring the inorganic soil $\mathrm{N}$-content $\left(\mathrm{NO}_{3}-\mathrm{N}\right.$ and $\left.\mathrm{NH}_{4}-\mathrm{N}\right)$.

Nitrogen and phosphorus represent the most limited macronutrients in tropical forages. Forage grasses are quite responsive to N-fertilizer; its applications may result in increasing crude protein $(\mathrm{CP})$, number of tillers and leaves, and consequently dry matter (DM) production, since other production factors are not limited [4]. Nitrogen-fertilizer in forage grasses has shown low-use efficiency on tropical climate region. Nitrogen-fertilizer is usually applied in intensive management systems and results in high $\mathrm{NH}_{3}-\mathrm{N}$ losses, causing low $\mathrm{N}$-use efficiency (NUE).

Using N-fertilizer in forage grass must be well thought because overrates of N-fertilizer can promote excess of forage biomass above the capacity of consumption of animal grazing; thus the stocking rate needs to be adjusted in accordance with forage availability. We must keep in mind that the response to $\mathrm{N}$-fertilizer is closely related to the adequate content of $\mathrm{P}, \mathrm{K}$, and other nutrients available in soil. Just $\mathrm{N}$ application in forages cannot result in a satisfactory increase of biomass production, if there are constraints of other nutrients in soil, occasioning in low NUE [5]. 
In order to increase $\mathrm{N}$-fertilizer efficiency in forage grasses, one must keep in mind that the concepts of best management practices (BMPs) for fertilizer application must be followed, which combines the Right source, Right rate, Right place, and Right time's (4R) nutrient stewardship [5]. These concepts are universally applied, but the adjustment of the $4 \mathrm{R}^{\prime} \mathrm{s}$ recommendation depends on site-specific conditions, thus the use of a specific nutrient rate for one location is unpractical and even more unrealistic for other regions. Based on the earlier explanation, this chapter introduces the concept of the $4 R^{\prime}$ s to direct BMPs to improve NUE in forage grasses, in order to combine all practices forward the best economic, social, and environment conditions.

\section{Nitrogen-use efficiency}

The concept of best management practices (BMPs) for fertilizer use is quite important to improve N-use efficiency (NUE) in forage grasses. In forage breeding programs, the application of NUE could be a useful tool to select forage genotypes with higher capacity of biomass production under lower amount of $\mathrm{N}$-fertilizer rate. The improvement of NUE can result in higher quantity and quality of dry matter production on grassland. Even with the majority of methodologies conducted using grain crops as shown in Table 1, the adaptation of these procedures can be well applied in forage grasses.

In general, the concept of NUE is associated with higher yield and low N-fertilizer input; thus, it can be achieved if other N-management has already applied. The use of $\mathrm{N}$-sources can change NUE and even the rate, place, and time of N-fertilizer. To improve NUE, it is a complex combination, where the concepts of BMPs must be followed step by step, which are associated with the Right rate, Right source, Right place, and Right time (4R's) of N-fertilizer application on forage grass or grain crops [5]. Thus, all the concepts reported in the following subheadings will achieve a higher dry matter production with low $\mathrm{N}$-input in the forage production, combined with social, economic, and environment benefits.

\begin{tabular}{|c|c|c|}
\hline $\mathrm{N}$-use efficiency index & Calculation & References \\
\hline $\begin{array}{l}\text { AEN = Agronomic } \\
\text { efficiency of applied N (kg yield increased per kg N } \\
\text { applied) }\end{array}$ & $\mathrm{AEN}=(\mathrm{YN}-\mathrm{Y} 0) / \mathrm{FN}$ & {$[51,52]$} \\
\hline NER $=\mathrm{N}$-efficiency ratio $(\mathrm{kg}$ of yield per $\mathrm{kg}$ of $\mathrm{N}$ in tissue) & $\begin{array}{l}\text { NER }=[(\text { Units of yield }) /(\text { Units of } \mathrm{N} \text { in } \\
\text { tissue })]\end{array}$ & [53] \\
\hline $\begin{array}{l}\text { PEN }=\text { Physiological efficiency of applied } \mathrm{N} \text { ( } \mathrm{kg} \text { yield } \\
\text { increase per kg increase in N-uptake from fertilizer) }\end{array}$ & $\mathrm{PEN}=(\mathrm{YN}-\mathrm{Y} 0) /(\mathrm{UN}-\mathrm{U} 0)$ & {$[51,52]$} \\
\hline NFR $=\mathrm{N}$-fertilizer recovery $(\%)$ & $\mathrm{NFR}(\%)=[(\mathrm{UN}-\mathrm{U} 0) /(\mathrm{FN})] \cdot 100$ & {$[52,54]$} \\
\hline SNS $=$ Soil N-recovery $(\%)$ & GNCu/GNCf multiplied by 100 & {$[52,54]$} \\
\hline
\end{tabular}

FN, the amount of (fertilizer) $\mathrm{N}$ applied $\left(\mathrm{kg} \mathrm{ha}^{-1}\right)$; $\mathrm{YN}$, forage yield with applied $\mathrm{N}\left(\mathrm{kg} \mathrm{ha}^{-1}\right)$; $\mathrm{Y} 0$, crop yield $\left(\mathrm{kg} \mathrm{ha}^{-1}\right)$ in a control treatment with no N; UN, total plant N-uptake in aboveground biomass at maturity $\left(\mathrm{kg} \mathrm{ha}^{-1}\right)$ in a plot that received $\mathrm{N}$; $\mathrm{U} 0$, the total $\mathrm{N}$-uptake in aboveground biomass at maturity $\left(\mathrm{kg} \mathrm{ha}^{-1}\right)$ in a plot that received no $\mathrm{N}$.

Table 1. Agronomic indices for N-use efficiency for forages. 
Another manner to assess fertilizer application is through the bioeconomic efficiency that is compiled by the conversion efficiency of $\mathrm{N}$-fertilizer into forage dry matter produced, by the efficiency that the produced forages are consumed by the grazing animal, and through the efficiency to convert forage into animal products [6].

\section{The $4 R^{\prime} s$ for $N$-fertilizer in forage grass}

The consequences of uncorrected N-management practice can have an impact on the increasing greenhouse gas (GHG) emission, $\mathrm{NH}_{3}-\mathrm{N}$ volatilization, N-runoff, and water eutrophication, which are directly associated with a negative impact on environment. The success of $\mathrm{N}$-fertilizer in forage depends on the combination of rate, source, place, and time of application.

In general, BMPs are followed by three management practices that include the combination of soil nutrient availability and forage requirement, fertilizer application, and decreased N-losses from soil. The BMPs for fertilizer application are based on the $4 R^{\prime}$ s nutrient stewardship (Right source, Right rate, Right place and Right time) (Figure 1). These concepts combined direct understanding on how one can advance under a sustainable agriculture. The $4 \mathrm{R}^{\prime} \mathrm{s}$ are considered universal; then the scientific practices that direct the $4 \mathrm{R}^{\prime} \mathrm{s}$ can be applied and adjusted in site-specific around the world. Therefore, for each region and even each farmer there will be a set of practices that are site-specific to implement the $4 R^{\prime}$ s nutrient stewardship. The idea to have just one common recommendation for $\mathrm{N}$-fertilizer cannot be followed any longer.

All strives to implement the $4 R^{\prime}$ s nutrient stewardship in grassland must be incentivized to improve NUE. The concern about high production cost and surrounding environment impact is quite evident in agricultural system, and $\mathrm{N}$-fertilizer has a great quota of increasing these problems due to its high mobility in soil through $\mathrm{NO}_{3}-\mathrm{N}$ leaching, ammonium volatilization $\left(\mathrm{NH}_{3}-\mathrm{N}\right)$, and nitrous oxide $\left(\mathrm{N}_{2} \mathrm{O}\right)$ emission [7].

In order to apply the $4 R^{\prime}$ s nutrients stewardship, it is important to keep in mind that the $4 R^{\prime} s$ concept is directly associated with economic, social, and environmental impact (Figure 1).

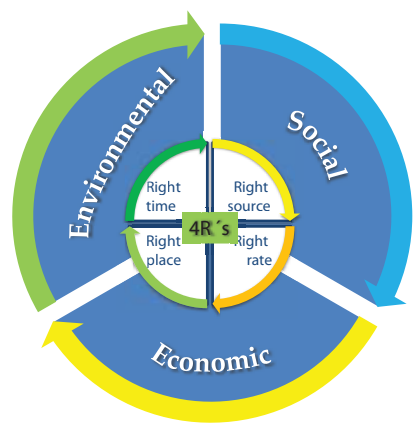

Figure 1. The $4 R^{\prime}$ s nutrient stewardship for $\mathrm{N}$-fertilizer in pastures. Adapted from Bruulsema et al. [5] and elaborated by the authors. 
The concepts shown in Figure 1 are interlinked; therefore, any decision in one of the $4 R^{\prime}$ s can influence directly on the results of N-fertilizer management and consequently on NUE.

\subsection{Right rate}

Nitrogen requirement for tropical forage and soil $\mathrm{N}$-supply must be balanced with $\mathrm{N}$-fertilizer rates, which is the most important nutrient removed from the soil in perennial pasture. Quantification of soil $\mathrm{N}$-availability is quite difficult; because $\mathrm{N}$ is very dynamic, changing from organic to inorganic forms depending on weather conditions, and soil feature, as aeration, bulk density, soil water content, moisture, etc. Thus, N-quantification through soil analysis becomes incorrect or not much realistic. On the other hand, for other nutrients like P, $\mathrm{K}, \mathrm{Ca}, \mathrm{Mg}$, S, and micronutrients, soil nutrient quantification using chemical extractors can result in accurate diagnosis.

Preview researches related to total $\mathrm{N}$ in soil quantify that $95 \%$ of the whole $\mathrm{N}$ in soil are combined in organic compounds that is available for plant uptake after the mineralization process, resulting in inorganic forms of $\mathrm{N}\left(\mathrm{NO}_{3}-\mathrm{N}\right.$ and $\left.\mathrm{NH}_{4}-\mathrm{N}\right)$ [8]. The total $\mathrm{N}$ in soil with pasture can achieve on average $2 \mathrm{Mg} \mathrm{ha}^{-1}$ of organic $\mathrm{N}$ with 5 years of pasture implemented under rotation with soybean and maize [9]. Consequently, the total $\mathrm{N}$ in soil and labile $\mathrm{N}$ are indicative of soil supply (Figure 2). In comparison to other crops and intercropping, B. ruziziensis and B. brizantha cv. Marandu cultivated without intercropping showed higher labile $\mathrm{N}$ in soil [9]. Thus, even with constraints in evaluating soil N-supply, the quantification of SOM, total N, and labile $\mathrm{N}$ can direct some information to guide the recommendation of $\mathrm{N}$-fertilizer rates.

Nitrogen is required by tropical forage in high amounts, and the answer has varied among the forage species which range from 200 to $1.800 \mathrm{~kg} \mathrm{~N} \mathrm{ha}^{-1}$ per year [9]. In order to recommend $\mathrm{N}$-fertilizer rates, besides the factors already mentioned, it is necessary to take into account

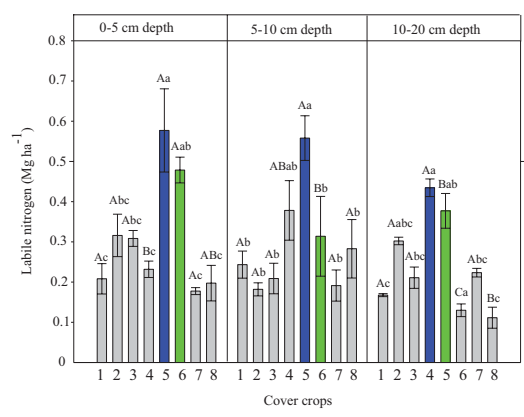

Figure 2. Cover crops and soil profile effects on labile nitrogen. Different uppercase letters indicate significant difference $(p \leq 0.05)$ among different soil depths within the same cover crop while the different lowercase letters indicate significant difference $(p \leq 0.05)$ among different cover crops within the same soil depth by Tukey test of means. The error bars are the standard errors. (1) Fall-winter corn; (2) Intercropping fall-winter corn with B. ruziziensis; (3) Intercropping fall-winter corn with B. brizantha cv. Marandu; (4) Intercropping fall-winter corn with C. spectabilis; (5) B. ruziziensis; (6) B. brizantha cv. Marandu; (7) Pennisetum glaucum L; (8) Fallow area. Fonte: Ensinas et al. [9]. 
the capacity of $\mathrm{N}$-fertilizer use efficiency by forage plants and its impact on the stocking rate. Thus, the amount of cattle herd is capable to consume the forage and the management for feeding to avoid excess and absence of forage [4].

Even with high response to $\mathrm{N}$-fertilizer rate by tropical forage, resulting in increasing crude protein (CP), and other bromatological features [10], the risk of higher downward residual $\mathrm{NO}_{3}-\mathrm{N}$ movement in soil and high concentration of $\mathrm{NO}_{3}-\mathrm{N}$ in biomass due to $\mathrm{N}$-fertilizer above plant requirement must be considered to avoid environment contamination and animal health problems [11, 12].

In order to increase forage biomass production, the balance of nutrients in soil and plants must be considered, and the constraint of other nutrients cannot be replaced by an increasing rate of $\mathrm{N}$-fertilizer, and thus the expected dry matter production associated with plant requirement is the guide to determine the appropriate $\mathrm{N}$-fertilizer rate. The low $\mathrm{S}$ supply may increase $\mathrm{NO}_{3}-\mathrm{N}$ accumulation and soluble protein in plant tissue [13], due to possible restriction in $\mathrm{NO}_{3}-\mathrm{N}$ reductase enzyme [14].

In a condition without $\mathrm{N}$-fertilizer, biological fixation of $\mathrm{N}_{2}$ and atmospheric deposition, the $\mathrm{N}$ available for forage plant uptakes is just the $\mathrm{N}$ mineralized from SOM [8]. Thus, avoiding $\mathrm{N}$-fertilizer in forage can deplete its biomass production over time, since soil $\mathrm{N}$-mineralization is slow and not able to supply forage requirement for a long time. One must keep in mind that grazed animals must consume the biomass production in forage; therefore, the stocking rate management must be taken into consideration to decide the $\mathrm{N}$-fertilizer rate.

Usually, the recommendation of $\mathrm{N}$-fertilizer in forage follows the concept of yield response with an expected production and stocking rate associated to consume the excess production, both associated with $\mathrm{N}$-fertilizer rate experiments in site-specific conditions.

\subsection{Right source}

Soil organic matter (SOM) is the highest supplier of $\mathrm{N}$ for forage growth, which can reach $85 \%$ of the whole $\mathrm{N}$ required by forages [15]; thus, the absence of $\mathrm{N}$-fertilizer rates to replace the plant uptakes can conduct to pasture degradation. Forage plants uptake $\mathrm{N}$ majority through nitrate $\left(\mathrm{NO}_{3}-\mathrm{N}\right)$ and ammonium $\left(\mathrm{NH}_{4}-\mathrm{N}\right)$ [16], which depend on their contents in soil solution (Figure 3). The proportion of $\mathrm{NO}_{3}-\mathrm{N}$ and $\mathrm{NH}_{4}-\mathrm{N}$ is determined by soil conditions, $\mathrm{NO}_{3}-\mathrm{N}$ can be predominant in aerobic condition where nitrification can occur. On the other hand, $\mathrm{NH}_{4}-\mathrm{N}$ can be predominant in acid soil and anaerobic soil. However, the assimilation of $\mathrm{NO}_{3}-\mathrm{N}$ in plants tends to expend to be more energetic than $\mathrm{NH}_{4}-\mathrm{N}$ assimilation. Through the action of inducible enzyme (nitrate reductase), the $\mathrm{NO}_{3}-\mathrm{N}$ is reduced to $\mathrm{NH}_{4}-\mathrm{N}$ and finally incorporated to glutamine [16]. When the uptake occurs through $\mathrm{NH}_{4}-\mathrm{N}$, the expenditure of energy with the $\mathrm{NO}_{3}-\mathrm{N}$ reduction is solved.

Good result in forage production was shown when $\mathrm{NO}_{3}-\mathrm{N}$ and $\mathrm{NH}_{4}-\mathrm{N}$ had 70 and $30 \%$ in soil, respectively $[17,18]$. On the other hand, the use of $\mathrm{NO}_{3}-\mathrm{N}: \mathrm{NH}_{4}-\mathrm{N}$ mixture at the ratio of $55: 45 \%$ instead of the $\mathrm{NO}_{3}-\mathrm{N}$ solely as $\mathrm{N}$ source in the nutrient solution enhanced the production of tillers (30\%), leaves (20\%), and the leaf area surface (30\%) of P. maximum Jacq. cv. Aruana (Aruana guineagrass) [12]. 


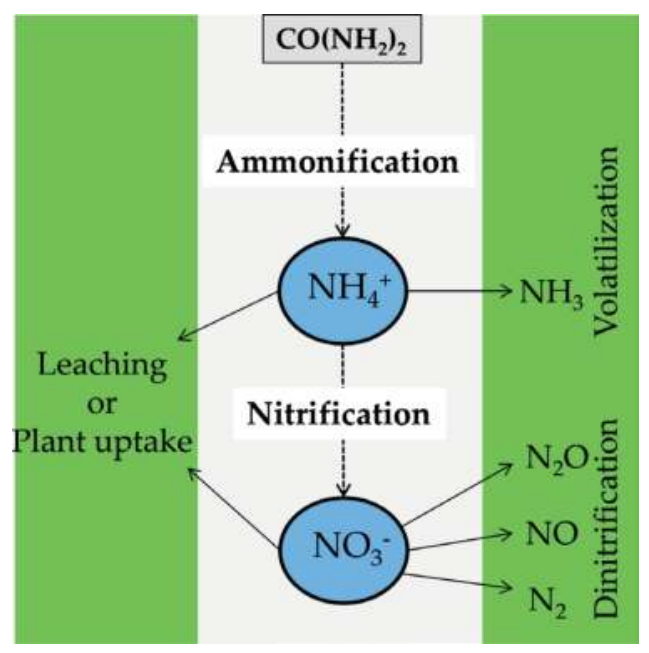

Figure 3. Summary of urea reaction on soil. Elaborated by authors.

Anyway, both forms of $\mathrm{N}\left(\mathrm{NO}_{3}\right.$ or $\left.\mathrm{NH}_{4}\right)$ are incorporated to amino acids through the glutamine synthetase-glutamate [19]. However, the major problem is the accumulation of $\mathrm{NO}_{3}-\mathrm{N}$ in forage, because high $\mathrm{NO}_{3}-\mathrm{N}$ concentrations (above $4500 \mathrm{mg} \mathrm{kg}^{-1}$ of dry matter considered highly toxic) can cause animal mortalities [20].

There are many $\mathrm{N}$-fertilizer sources for use in forage (Table 2). Nitrogen-fertilizer sources with a higher content of $\mathrm{N}$ are preferable to apply in grassland due to lower transport cost and facility of application. Urea, ammonium sulfate, and nitrate are the three majority sources of $\mathrm{N}$ used in forage grass. However, each of them has peculiarity in relation to using in forage with its pros and cons.

On the one hand, urea $\left[\mathrm{CO}\left(\mathrm{NH}_{2}\right)_{2}\right]$ shows the highest concentration of $\mathrm{N}$ (Table 2), and lower price per $\mathrm{N}$ unit in its composition, and causes less soil acidification compared with ammonium sulfate [21], on the other hand, urea is the $\mathrm{N}$-fertilizer source that causes higher $\mathrm{NH}_{3}-\mathrm{N}$ losses through volatilization [16], and consequently lower NUE.

In order to decrease losses of $\mathrm{NH}_{3}-\mathrm{N}$ from urea source, the application in season with higher rainfall would be indicated, and as other alternative, the use of urea with the inhibitor of urease can be a viable alternative in forage grass; nevertheless, the still high cost of urea with urease inhibitor can restraint its use in forage grass. In studying with six sources of $\mathrm{N}$-fertilizer B. brizantha cv. Marandu, it was observed that N-sources do not change the performance of dry matter; however, urea with urease inhibitor and polymer-coated urea improved NUE [22]. Urea mechanical incorporation or rain after $\mathrm{N}$-fertilizer application can decrease the amount of $\mathrm{NH}_{3}-\mathrm{N}$ losses, due to higher speed of urea incorporated in soil [11].

Ammonium sulfate $\left[\left(\mathrm{NH}_{4}\right)_{2} \mathrm{SO}_{4}\right]$ has $22 \%$ of sulfur $(\mathrm{S})$ and $20 \%$ of $\mathrm{N}$ in composition (Table 2); this $\mathrm{S}$ content is quite interesting because of the improvement of $\mathrm{N}$-use efficiency by forages. 


\begin{tabular}{lll}
\hline Fertilizer source & \multicolumn{2}{l}{ Minimum guarantee } \\
\cline { 2 - 3 } & $\begin{array}{l}\text { Nutrient content } \\
\text { and form }\end{array}$ & Nutrient solubility/granulometry \\
\hline Urea & $45 \%$ of $\mathrm{N}$ & Total content of $\mathrm{N}$. \\
Ammonium sulfate & $20 \%$ of $\mathrm{N}$ & Total content of $\mathrm{N}$ and $\mathrm{S}$. \\
& $22 \%$ of $\mathrm{S}$ & \\
Fosfato Diamônico (DAP) & $17 \%$ of $\mathrm{N}$ & Total content of $\mathrm{N}$ and $\mathrm{P}_{2} \mathrm{O}_{5}$ content soluble in CNA plus \\
& $45 \%$ of $\mathrm{P}_{2} \mathrm{O}_{5}$ & water and minimum of $44 \%$ soluble in water. \\
Fosfato Monoamônico (MAP) & $9 \%$ of $\mathrm{N}_{2}$ & Total content of $\mathrm{N}$ and $\mathrm{P}_{2} \mathrm{O}_{5}$ content soluble in CNA plus \\
& $48 \%$ of $\mathrm{P}_{2} \mathrm{O}_{5}$ & water and minimum of $44 \%$ soluble in water. \\
Ammonium nitrate & $32 \%$ of $\mathrm{N}$ & Total content of $\mathrm{N}$. \\
\hline
\end{tabular}

Fonte: Adapted from Agricultural Ministry (MAPA), Normative Instruction No. 46, November 22, 2016.

Table 2. Major N-sources, specification of the simple solid sources of nitrogen with minimum granulometric guarantee.

Nevertheless, ammonium sulfate acidifies the soil due to the nitrification process. Among urea, ammonium sulfate, and potassium nitrate fertilizers applied in forage grasses, ammonium sulfate has the highest capacity to increase soil acidity [23].

Nitrogen and $S$ are closely related to plant metabolism, resulting in increasing protein content when both are in adequate balance for forage. The ratio of N/S for B. brizantha (Hochst. ex A. Rich.) Stapf. cv. Marandu was 10/1; the fertilization promoted high yield, adequate N- and S-concentrations for plant metabolism, and forage production, as well as maintained and/or raised the soil fertility in relation to these nutrients [24].

In a study published by [25], the optimum N/S ratio was 14.02 in a high-yielding population defined through method DRIS (diagnosis and recommendation-integrated system). In order to use ammonium sulfate source, it is recommended to apply liming to correct the acidity promoted by this N-source.

Another way to improve $\mathrm{N}$-availability to forage grass is the mixture of legumes and pasture. In Brazil, the native Stylosanthes spp. are used in mixture with Brachiaria spp. The use of a mixture of legume with gramineas is quite interesting to reduce $\mathrm{N}$-fertilizer rate due to legume capacity to fix molecular $\mathrm{N}_{2}$ from atmosphere, but it is still a challenge to maintain the right proportion of these two species without competition, because the legume tends to disappear due to competition $[26,27]$.

Besides legumes, which has symbiotic association with microorganism in root system, Brachiaria spp. may be partially $\mathrm{N}$ supplied by inoculation with Azospirillum amazonense. The association of $B$. brizantha, $B$. decumbens, and B. humidicola with $A$. amazonense was observed by [28], which reported the capacity of $A$. amazonense in producing hormones as indole-3-acetic acid (IAA, 3-IAA). Accordingly, the inoculation of A. amazonenses with Brachiaria spp. may result in positive interaction, resulting in such improvement in promoting the growth of forages. The association of Brachiaria spp. and Ancylostoma brazilienses may promote increasing 
$\mathrm{N}$-accumulation respective to $40 \mathrm{~kg} \mathrm{ha}^{-1}$ of $\mathrm{N}$-fertilizer rate. Besides previous information about Brachiaria spp. inoculation with Azospirillum spp., much more researches must be taken for better understanding about the efficiency of Brachiaria spp. inoculation.

Microorganisms in soil provide great contribution in $\mathrm{N}$-availability through mineralization of SOM, basically due to enzyme activity in mineralization process. There are important correlations between microbial biomass carbon (C-MBC) and microbial biomass nitrogen $(\mathrm{N}-\mathrm{MBN})$ [29]. In general, in crop rotation system the rate of C-MBC:C-organic and N-MBM:N-total is 1.1 and $2.6 \%$, respectively, while in single crop the rate is 0.8 and $2.1 \%$ [30]. As reported by [29], in pasture system values of 2.4 and 3.2\% (N-MBM:C-MBC) were observed.

Under pasture system, the species of forages and soil cover promoted significant effect on $\mathrm{C}-\mathrm{MBC}$ and enzymatic activity; therefore, these enzymes can be used as indicator of soil quality [29]. Even with equal C-MBC and N-MBN, the activity of urease, protease, and dehydrogenase in pasture was different [29]. The intensity and forms of different plant species influenced in $\mathrm{N}$-cycle require further studying. As reported by [31], in order to increase the availability of inorganic $\mathrm{N}$ through the action of root exudates, the $\mathrm{N}$-microbial mineralization depends on $\mathrm{C}$ availability and labile N. Depending on the type of exudation, the losses of $\mathrm{N}_{2}$ to atmosphere can be increased due to reduction of $\mathrm{N}_{2} \mathrm{O}$ to $\mathrm{N}_{2}$ [31]. The importance of microorganism in improving $\mathrm{N}$ through mineralization is crucial in soil, which needs more researches in forage grass to improve our knowledge in $\mathrm{N}$ dynamic into this production system.

\subsection{Right place}

Broadcasting without incorporation is a common manner to apply $\mathrm{N}$-fertilizer in forage grasses in tropical forage. Even with less effective for improvement of NUE, N-fertilizer broadcasting is considered the most practical procedure to apply in larger areas of livestock in tropical climate as the case of Brazil. Besides, this widely used procedure, there are other placement methods that can be used in forage and have already been applied successfully, as the case of banding $\mathrm{N}$-fertilizer incorporated in soil [32]. The $\mathrm{N}$-fertilizer incorporation is the most effective way to decrease $\mathrm{NH}_{3}-\mathrm{N}$ and increase NUE when $\mathrm{N}$-fertilizer source is the common urea. Conversely, the mechanical incorporation of $\mathrm{N}$-fertilizer in pasture sometimes is not possible due to the absence of adequate implement faced by most farmers. Broadcasting ammonium nitrate and ammonium sulfate on soil surface is effective due to low $\mathrm{NH}_{3}-\mathrm{N}$ gas volatilization from both $\mathrm{N}$-fertilizer sources.

Applications of urea broadcasting usually show a lower capacity of $\mathrm{N}$-fertilizer recovery, resulting in biomass production of forages below the expected. Urea applied in soil depth markedly reduces the $\mathrm{NH}_{3}-\mathrm{N}$ gas volatilization without causing serious damage to forages; however, it is not common among Brazilian farmers. The placement of urea on soil surface can decrease above $40 \%$ of the whole $\mathrm{N}$-fertilizer applied in forage grass [15]. Ammonia volatilization resulted from urea application may cause environmental impact, with increasing 
the $\mathrm{NH}_{3}-\mathrm{N}$ in site-specific surrounding of $85 \%$ of the total $\mathrm{NH}_{3}-\mathrm{N}$ volatilized, and the remaining $\mathrm{NH}_{3}-\mathrm{N}$ is conducted to another region through winds [33].

Urea with the inhibitor of urease is an alternative to reduce $\mathrm{NH}_{3}-\mathrm{N}$ volatilization and $\mathrm{N}_{2} \mathrm{O}$ when urea is broadcasting without incorporation [34], occasioning a lower content of $\mathrm{NO}_{3}-\mathrm{N}$ and $\mathrm{NH}_{4}-\mathrm{N}$ in soil, but increasing the plant uptake due to higher availability though time [35].

\subsection{Right time}

In order to optimize $\mathrm{N}$-fertilizer use efficiency for pastures, the right time is decisive to achieve better results in terms of nutrient uptake and biomass production. The time of $\mathrm{N}$-fertilizer application in forage grass varies through the growing season and higher demand of nutrients by plants. In tropical region, $\mathrm{N}$-uptake is highly demanded in summer season, because of the highest biomass accumulation due to higher rainfall, adequate temperature, and sunlight for optimum forage growth (Figure 4). The highest plant N-requirement is the right time for $\mathrm{N}$-fertilizer in forage grasses [36], because it tends to improve $\mathrm{N}$-uptake by plants and consequently NUE. For implementation of pasture, the application of $\mathrm{N}$-fertilizer used to show low efficiency due to low plant requirement in the beginning of growth, and SOM mineralization tends to be enough for initial growth.

Even with the suggestion for N-fertilizer time shown in Figure 4, time is dependent of intensive or extensive livestock system. In rotated grazing, it is used to apply $\mathrm{N}$-fertilizer right after rotated animal. On the other hand, in extensive system $\mathrm{N}$-fertilizer can follow the application time as suggested in Figure 4. The rainfall information needs to be obtained in site-specific



Figure 4. Average rainfall, and maximum and minimum temperature of 21 years. Data from meteorological station of Universidade Federal da Grande Dourados (UFGD), Mato Grosso do Sul State, Brazil. A dashed line means the boundary of water limitation to produce forage dry matter. 
region to manage and develop the right time to maximize the NUE by forage grass. N-fertilizer application in dry season tends to show lower NUE due to water limitation for plant nutrient uptake, which is not recommended because of cost-effective being low.

Summer season is considered the best moment to apply N-fertilizer in forage grasses, resulting in higher NUE due to rainfall enough for better growth. In order to avoid the seasonality of forage growth, even with low NUE in comparison to summer season, the application of $\mathrm{N}$-fertilizer at the end of summer season (March) can help to decrease the growth seasonality (Figure 4). In a study with rates of $\mathrm{N}$ and irrigation for B. brizantha cv. Marandu in two periods of the year (dry and wet season) in the IIha Solteira City, Sao Paulo State, Brazil, it was observed that in the wet season, the average DM yield of Marandu grass was $1.9 \mathrm{t} \mathrm{ha}^{-1}$ in the irrigated experiment and $1.8 \mathrm{tha}^{-1}$ in the non-irrigated experiment, that is, with no statistically significant difference [37]. In the dry season, the average DM yields were $8.1 \mathrm{t} \mathrm{ha}^{-1}$ in the irrigated treatment and $4.4 \mathrm{tha}^{-1}$ under non-irrigated treatment. The irrigated experiment produced $55 \%$ more than the non-irrigated one.

\section{N-concentration and crude protein $(\mathrm{CP})$ content in forage dry matter}

The contents of $\mathrm{CP}$ are affected by $\mathrm{N}$-fertilizer rates applied in each forage cut or rotated grazing, and by physiologic age of forage [12]. The measurement of CP in dry matter (DM) of forage is directly related to $\mathrm{N}$-concentration in $\mathrm{DM}$, where the amount of $\mathrm{CP}$ is the multiplication of $\mathrm{N}$-concentration by 6.25 [8]. The coefficient is related to $\mathrm{N}$-proportion in vegetal protein. However, this content of $\mathrm{CP}$ does not reflect just the real amount of crude protein because it is related to all $\mathrm{N}$ forms in tissue, even the $\mathrm{NO}_{3}-\mathrm{N}$ accounts to result in this amount of $\mathrm{CP}$ [10].

Nitrogen balanced in forage can result in higher leaf/stem ratio, palatability, and succulence in forages [10]. According to Cornell or CNCPS model [38], the CP of forage plants and foods is divided into five fractions. The soluble part of protein is divided by $\mathrm{A}$ and $\mathrm{B} 1$ fractions. The fraction $\mathrm{A}$ is the $\mathrm{N}$ no-protein $(\mathrm{NnP})$, since this fraction is highly soluble in rumen. The remaining $\mathrm{B} 1$ fraction is part of true protein, which also shows fast degradation in rumen. The fraction $\mathrm{C}$ corresponds to the unavailable protein and it is the part of protein content in acid detergent fiber $(\mathrm{ADF})$, non-soluble $\mathrm{N}$ in acid detergent (nADF). These associations of lignin result in tannin complex and products from Maillard reactions that are resistant to microbial enzymatic degradation. The fraction of $\mathrm{N}$ in neutral detergent fiber (NDF) is denominated by $\mathrm{N}$ non-soluble in neutral detergent (nNDF). Another form of available protein in plant is the subtraction of nADF and $\mathrm{nNDF}$, which are designated as the fraction B3; however, the rate of degradation is quite slow. The B2 fraction is the last, which shows medium degradation and is considered the non-soluble protein fraction; thus, the $\mathrm{B} 2$ fraction does not make a part of the cell wall and non-protein $\mathrm{N}$.

Crude protein fractionation is not commonly done in researches related to tropical forages; however, in some scientific results related to $\mathrm{N}$-fertilizer an increase in $\mathrm{CP}$ and a decrease in $\mathrm{nADF}$ (fraction $\mathrm{C}$ ) occur. The decrease in fraction $\mathrm{C}$ is desirable, because this fraction compiles the non-soluble protein, which is not degraded in the rumen [39-41]. 


\section{Greenhouse gas (GHG) emissions in grazed pasture under $\mathrm{N}$-fertilizer}

The three most important greenhouse gases (GHG) in the atmosphere are carbon dioxide $\left(\mathrm{CO}_{2}\right)$, methane $\left(\mathrm{CH}_{4}\right)$, and nitrous oxide $\left(\mathrm{N}_{2} \mathrm{O}\right)$. Both of them are strongly affected by $\mathrm{N}$-fertilizer in agricultural system [42], with a major responsibility of agriculture for methane $\left(\mathrm{CH}_{4}\right)$ and nitrous oxide $\left(\mathrm{N}_{2} \mathrm{O}\right)$ emissions $[43,44]$.

Nitrous oxide is 310 times more dangerous for stratospheric ozone $\left(\mathrm{O}_{3}\right)$ than $\mathrm{CO}_{2}$ and shows a lifetime of 112 years in the stratosphere [45]. Nitrous oxide emission in grazed pasture is associated with animal stocking rate, animal excreta (urine and dungs), content of soil $\mathrm{NO}_{3}-\mathrm{N}, \mathrm{N}$-fertilizer rates, tillage, soil moisture, soil compaction, and other process that affect soil aeration [7, 42].

Nitrous oxide is a way of $\mathrm{N}$-losses in grazed pasture, as well as $\mathrm{NO}_{3}-\mathrm{N}$ leaching and $\mathrm{NH}_{3}-\mathrm{N}$ volatilization; both forms of $\mathrm{N}$-losses are related to environment depletion [47]. Nitrogenfertilizer efficiency is directly related to $\mathrm{N}_{2} \mathrm{O}$ emission, which is termed denitrification process $[16,46,47]$. In Brazilian Cerrado, the $\mathrm{NH}_{3}-\mathrm{N}$ and $\mathrm{N}_{2} \mathrm{O}$ through denitrification were observed to be the most important process of N-losses from cattle excreta for 7 months of rainy season in extensive pasture [48]. As reported by [7], the emission of $\mathrm{N}_{2} \mathrm{O}$ in grazed pastures is partially associated with $\mathrm{C}$ and $\mathrm{N}$ deposited from the animal excreta on soil (urine and dungs) under anaerobic conditions, as the case of soil compaction caused by animal trampling.

The anaerobic circumstance can be observed in wet soil after animal trampling [7]; thus, the $\mathrm{N}$-fertilizer applied under wet condition can increase the $\mathrm{N}_{2} \mathrm{O}$ emission through $\mathrm{NO}_{3}-\mathrm{N}$ content in soil that can be denitrified in pasture. The use of $\mathrm{N}$-fertilizer sources with the inhibitor of urease and nitrification can reduce the $\mathrm{N}_{2} \mathrm{O}$ emission [49], due to slow process of urea hydrolase and permanence of $\mathrm{NH}_{4}-\mathrm{N}$ form instead of $\mathrm{NO}_{3}-\mathrm{N}$.

Urine and dungs excreta by grazed animals are responsible for a great source of $\mathrm{N}_{2} \mathrm{O}$ emission in grazed pastures. Integrated crop-livestock-forestry (ICLFS) or livestock-forestry system (ILFS)

(A)

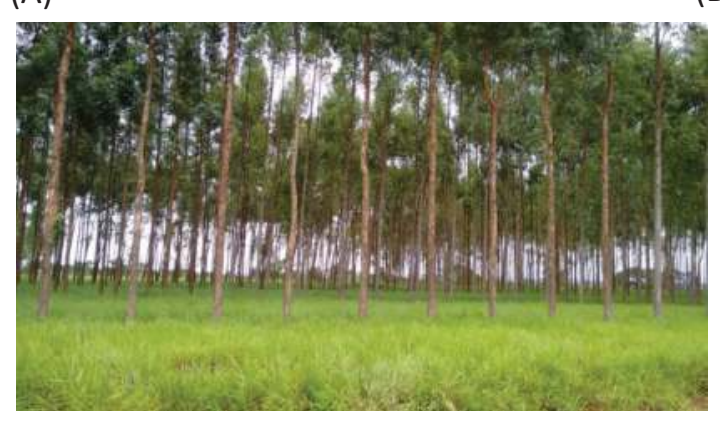

(B)

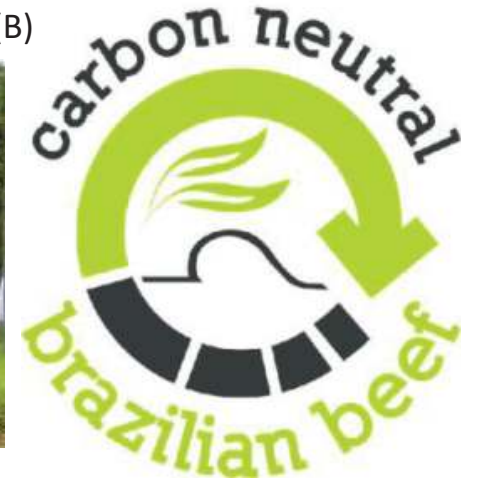

Figure 5. (A) Integrated crop-livestock-forestry system located in Embrapa Beef Cattle (Source: Dr. Ademar P. Serra); and (B) the brand of carbon neutral Brazilian beef (CNBB) concept (Developed by the Brazilian Agricultural Research Corporation (Embrapa Beef Cattle)). 
can show a positive budget in mitigation GHG. The use of trees in ICLFS or ILFS has achieved positive budged in sequestrated $\mathrm{CO}_{2}$ equivalent in integrated system (Figure 5A). Brazilian Agricultural Research Corporation (Embrapa beef cattle) launched the concept of neutral carbon meat (NCM) (Figure 5B) [50], which are possible to affirm that the trees in ICLFS and ILFS have the capacity to neutralize the entire emission of GHG into this production system.

\section{Concluding remarks}

The $4 R^{\prime}$ s nutrient stewardship is universal, requiring adjustment in site-specific to improve the $\mathrm{N}$-use efficiency. Based on the $4 \mathrm{R}^{\prime} \mathrm{s}$, it is possible to direct the best management practices (BMPs) to achieve sustainable agricultural. The $4 \mathrm{R}^{\prime} \mathrm{s}$ must be well defined in order to obtain higher $\mathrm{N}$-fertilizer use, consequently decreasing in social, economic, and environmental negative impact, resulting in increased nutrient use efficiency associated with high yielding.

A mixture of Brachiaria spp. with legumes must be incentivized to decrease the use of $\mathrm{N}$-sources in forage grasses; however, the competition between species requires more understanding in order to avoid legume degradation in mixture with Brachiaria spp.

In order to improve NUE in forage grass, the N-fertilizer must be applied in the right rate, with the right source, followed by the right time and place; this is the sequence that one needs to keep in mind to adjust the $4 R^{\prime}$ s in site-specific to achieve social benefits with the absence of negative environmental impact and improvement of economic returns.

The $4 R^{\prime}$ s are interrelated and $N$-fertilizer rates cannot be recommended without the combination of the $4 R^{\prime}$ s where a whole system to be followed should be considered to decide about $\mathrm{N}$-fertilizer in pasture. One must keep in mind that the modification of one principal is going to affect the result of the other.

The possibility to sequestrated greenhouse gas in integrated livestock-forestry system (ILFS) is quite important for the environment. As was reported in this chapter, the implementation of trees in integrated systems can neutralize the whole emission of GHG by cattle.

\section{Author details}

Ademar Pereira Serra ${ }^{1 *}$, Marlene Estevão Marchetti², Elisângela Dupas²,

Simone Candido Ensinas ${ }^{3}$, Elaine Reis Pinheiro Lourente ${ }^{2}$, Eulene Francisco da Silva ${ }^{4}$, Roberto Giolo de Almeida ${ }^{1}$, Carla Eloize Carducci ${ }^{2}$ and Alessandra Mayumi Tokura Alovisi ${ }^{2}$

*Address all correspondence to: ademar.serra@embrapa.br

1 Brazilian Agricultural Research Corporation (EMBRAPA), Campo Grande, Brazil

2 Federal University of Grande Dourados (UFGD), Dourados, Brazil

3 State University of Mato Grosso do Sul (UEMS), Cassilândia, Brazil

4 Federal Rural University of the Semi-arid Region (UFERSA), Mossoró, Brazil 


\section{References}

[1] McManus C, Barcellos JOJ, Formenton BK, Hermuche PM, Carvalho OA Jr, Guimarães R. Dynamics of cattle production in Brazil. PloS One. 2016;11:1-15. DOI: 10.1371/journal. pone. 0147138

[2] Euclides VPB, Valle CB, Macedo MCM, Almeida RG, Montagner DB, Barbosa RA. Brazilian scientific progress in pasture research during the first decade of XXI century. Revista Brasileira de Zootecnia. 2010;39:151-168

[3] Alexandratos N, Bruinsma J. World Agriculture Towards 2030/2050: The 2012 Revision. Food and Agriculture Organization of the United Nations, ESA Working Paper No. 12-03; June 2012

[4] Monteiro FA. Uso de corretivos e fertilizantes. In: Reis RA, GRS B, Siqueira GR, editors. Forragicultura: Ciência, Tecnologia e Gestão de Recursos Forrageiros. Jaboticabal: Maria de Lourdes Brandel - ME; 2013. p. 275-290

[5] Bruulsema T, Lemunyon J, Herz B. Know your fertilizer rights. Crops and Soils. 2009;42:13-18

[6] Martha JGB, Vilela L, Sousa DMG, Barcellos AO. Adubação nitrogenada. In: JGB M, Vilela L, DMG S, editors. Cerrado: uso eficiente de corretivos e fertilizantes em pastagens. 1st ed. Embrapa Cerrados: Planaltina; 2007. p. 117-144

[7] Luo J, Klein CAM, Ledgard SF, Saggar S. Management options to reduce nitrous oxide emissions from intensively grazed pastures: A review. Agriculture, Ecosystems \& Environment. 2010;136:282-291

[8] Whitehead DC. Nutrient Elements in Grassland: Soil-Plant-Animal Relationship. Oxford: Cabi Publishing; 2000. 363 p

[9] Ensinas SC, Serra AP, Marchetti ME, Silva EF, Prado EAF, Lourente ERP, Altomar PH, Potrich DC, Martinez MA, Conrad VA, Jesus MV, Kadri TCE. Cover crops affects on soil organic matter fractions under no till system. Australian Journal of Crop Science. 2016;10:503-512

[10] Ghosh PK, Palsaniya DR, Rai AK, Kumar S. Strategies for higher nutrient use efficiency and productivity in forage crops. In: Rakshit A, Singh HB, Sen A, editors. Nutrient Use Efficiency: From Basics to Advances. 1st ed. India: Springer; 2014. p. 329-342. DOI: 10.1007/978-81-322-2169-2_21

[11] Di HJ, Cameron KC. Reducing environmental impacts of agriculture by using a fine particle suspension nitrification inhibitor to decrease nitrate leaching from grazed pastures. Agriculture, Ecosystems and Environment. 2005;109:202-212

[12] Santos FAS, Dórea JRR, Gouvêa VN. Compostos nitrogenados em plantas forrageiras. In: Reis RA, Bernardes GRS, Siqueira GR, editors. Forragicultura: Ciência, Tecnologia e Gestão de Recursos Forrageiros. 1st ed. Jaboticabal: Maria de Lourdes Brandel - ME; 2013. p. 395-407 
[13] Schmidt F, Bona FD, Monteiro FA. Sulfur limitation increases nitrate and amino acid pools in tropical forages. Crop and pasture. Science. 2013;64:51-60. DOI: 10.1071/CP12336

[14] De Bona FD, Fedoseyenko D, Von Wirén N, Monteiro FA. Nitrogen utilization by sulfurdeficient barley plants depends on the nitrogen form. Environmental and Experimental Botany. 2011;74:237-244. DOI: 10.1016/j.envexpbot.2011.06.005

[15] Rowlings DW, Scheer C, Liu S, Grace PR. Annual nitrogen dynamics and urea fertilizer recoveries from a dairy pasture using $15 \mathrm{~N}$; effect of nitrification inhibitor DMPP and reduced application rates. Agriculture, Ecosystems \& Environment. 2016;216:216-225. DOI: 10.1016/j.agee.2015.09.025

[16] Marschner P, Rengel Z. Nutrient Cycling in Terrestrial Ecosystems. Berlin, Germany: Springer-Verlag Berlin; 2007. 291 p

[17] Santos JHS. Proporções de nitrato e amônio na nutrição e produção dos capins Aruana e Marandu [thesis]. Piracicaba: Escola Superior de Agricultura "Luiz de Queiroz", Universidade de São Paulo; 2003

[18] De Bona FD. Nitrogênio e enxofre para gramínea forrageira: Atributos do solo e aspectos metabólicos, nutricionais e produtivos da planta [thesis]. Piracicaba: Escola Superior de Agricultura "Luiz de Queiroz", Universidade de São Paulo; 2008

[19] Marschner P. Marschner's Mineral Nutrition of Higher Plants. 3rd ed. London: Elsevier; 2012. $643 \mathrm{p}$

[20] Sidhu PK, Bedi GK, Mahajan MV, Sharma S, Sandhu KS, Gupta MP. Evaluation of factors contributing to excessive nitrate accumulation in fodder crops leading to illhealth in dairy animals. Toxicology International. 2011 Jan-Jun;18(1):22-26. DOI: 10.4103/0971-6580.75848

[21] Primavesi AC, Primavesi O, Correa LA, Cantarella H, Silva AG, Freitas AR, Vivaldi LJ. Adubação nitrogenada em capim-coastcross: Efeitos na extração de nutrientes e recuperação aparente do nitrogênio. Revista da Sociedade Brasileira de Zootecnia. 2004;33:68-78

[22] Dupas E, Buzetti S, Rabelo FHS, Sarto AL, Cheng NC, Teixeira Filho MCM, Galindo FS, Dinalli RP, Gazola RN. Nitrogen recovery, use efficiency, dry matter yield, and chemical composition of palisade grass fertilized with nitrogen sources in the Cerrado biome. Australian Journal of Crop Science. 2016;10:1330-1338

[23] Faccin FC, Marchetti ME, Serra AP, Ensinas SC. Frações granulométricas da matéria orgânica do solo em consórcio de milho safrinha com capim-marandu sob fontes de nitrogênio. Pesquisa Agropecuária Brasileira. 2016;51:2000-2009

[24] De Bona FD, Monteiro FA. Marandu palisadegrass growth under nitrogen and sulphur for replacing signal grass in degraded tropical pasture. Scientia Agricola. 2010;67:570578. DOI: 10.1590/S0103-90162010000500011

[25] Silveira CP, Nachtigall GR, Monteiro FA. Norms for the diagnosis and recommendation integrated system for signal grass. Scientia Agricola. 2005;62:513-519 
[26] Andrade CMS, Garcia R, Couto L, Pereira OG, Souza AL. Desempenho de Seis Gramíneas Solteiras ou Consorciadas com o Stylosanthes guianensis cv. Mineirão e Eucalipto em Sistema Silvipastoril. Revista Brasileira de Zootecnia. 2003;32:1845-1850

[27] Olanite JA, Tarawali SA, Aken'ova ME. Biomass yield, quality and acceptability of selected grass-legume mixtures in the moist savannah of west Africa. Tropical Grasslands. 2004;38:117-128

[28] Reis Junior FB, Silva MF, Teixeira KRS, Urquiaga S, Reis VM. Identification of Azospirillum amazonense isolates associated to brachiaria spp. at different stages and growth conditions, and bacterial plant hormone production. Revista Brasileira de Ciência do Solo. 2004;28:103-113

[29] Lu X, Fan J, Yan Y, Wang X. Comparison of soil microbial biomass and enzyme activities among three alpine grassland types in northern Tibet. Polish Journal of Environmental Studies. 2013;22:437-443

[30] Moore JM, Klose S, Tabatabai MA. Soil microbial biomass carbon and nitrogen as affected by cropping systems. Biology and Fertility of Soils. 2000;31:200-2010

[31] Jackson LE, Bowles TM, Hodson AK, Lazcano C. Soil microbial-root and microbial-rhizosphere processes to increase nitrogen availability and retention in agroecosystems. Current Opinion in Environmental Sustainability. 2012;4:517-522

[32] Asgedom H, Kebreab E. Beneficial management practices and mitigation of greenhouse gas emissions in the agriculture of the Canadian prairie: A review. Agronomy for Sustainable Development. 2011;31:433-451. DOI: 10.1007/s13593-011-0016-2

[33] Bouwman AF, Boumans LJM, Batjes NH. Estimation of global NH3 volatilization loss from synthetic fertilizers and animal manure applied to arable lands and grasslands. Global of Biogeochemical Cycles. 2002;6:8-14. DOI: 10.1029/2000GB001389

[34] Soares JR, Cantarella H, Menegale MLC. Ammonia volatilization losses from surfaceapplied urea with urease and nitrification inhibitors. Soil Biology and Biochemistry. 2012;52:82-89

[35] Singh J, Kunhikrishnan A, Bolan NS, Saggar S. Impact of urease inhibitor on ammonia and nitrous oxide emissions from temperate pasture soil cores receiving urea fertilizer and cattle urine. Science of the Total Environment. 2013;465:56-63

[36] Di HJ, Cameron KC. Nitrate leaching in temperate agroecosystems: Sources, factors and mitigating strategies. Nutrient Cycling in Agroecosystems. 2002;46:237-256

[37] Dupas E, Buzett S, Sarto AL, Hernandez FBT, Bergamaschine AF. Dry matter yield and nutritional value of Marandu grass under nitrogen fertilization and irrigation in Cerrado in Sao Paulo. Revista Brasileira de Zootecnia. 2010;39:2598-2603

[38] Snnifen CJ, O'Connor JD, Van Soest PJ, Fox DG, Russel JB. A net carbohydrate and protein system for evaluating cattle diets: II. Carbohydrate and protein availability. Journal of Animal Science. 1992;70:3562-3577 
[39] Dupas E. Nitrogen potassium and boron: Productive, morphological and nutritional parameters and fibers and protein fractions of Tanzania guinegrass [thesis]. Piracicaba: Escola Superior de Agricultura “Luiz de Queiroz”, Universidade de São Paulo; 2012

[40] Oliveira RL, Barbosa MAAF, Cecato U, Matos RC, Rodrigues A, Santiago MS. Carbohydrate and protein fractions of Mombaça grass under different cutting intervals and nitrogen levels. Biotechnology in Animal Husbandry. 2004;20:163-167

[41] Johnson CR, Reiling BA, Mislevy P, Hall MB. Effects of nitrogen fertilization and harvest date on yield, digestibility, fiber, and protein fractions of tropical grasses. Journal of Animal Science. 2001;79:2439-2448

[42] Inselsbacher E, Wanek W, Ripka K, Hack E, Sessitsch A, Strauss J, Zechmeister-Boltenstern S. Greenhouse gas fluxes respond to different $\mathrm{N}$ fertilizer types due to altered plant-soilmicrobe interactions. Plant and Soil. 2011;343:17-35. DOI: 10.1007/s11104-010-0597-6

[43] IPCC. Climate change 2007: Synthesis report. In: Team CW, Pachauri RK, Reisinger A, editors. Contribution of Working Groups I, II and III to the Fourth Assessment Report of the Intergovernmental Panel on Climate Change. Geneva: IPCC; 2007

[44] Reay DS, Davidson EA, Smith KA, Smith P, Melillo JM, Dentener F, Crutzen PJ. Global agriculture and nitrous oxide emissions. Nature of Climate Change. 2012;2:410-416. DOI: $10.1038 /$ nclimate1458

[45] IPCC. Climate change 2007: The physical science basis. In: Solomon S, Qin D, Manning M, Chen Z, Marquis M, Averyt KB, Tignor M, Miller HL, editors. Intergovernmental Panel on Climate Change. Cambridge/New York, NY, UK/USA: Cambridge University Press; 2007. $996 \mathrm{p}$

[46] Halving JL, Beaton JD, Tisdale SL, Nelson WR. Soil Fertility and Fertilizers: An Introduction to Nutrient Management. 6th ed. NJ: Prentice Hall; 1999528 p

[47] Zaman M, Saggar S, Blennerhassett J, Singh J. Effect of urease and nitrification inhibitors on $\mathrm{N}$ transformation, gaseous emissions of ammonia and nitrous oxide, pasture yield and N uptake in grazed pasture system. Soil Biology and Biochemistry. 2009;41:1270-1280

[48] Lessa ACR, Madari BE, Paredes DS, Boddey RM, Urquiaga S, Jantalia CP, Alves BJR. Bovine urine and dung deposited on Brazilian savannah pastures contribute differently to direct and indirect soil nitrous oxide emissions. Agriculture, Ecosystems and Environment. 2014;190:104-111

[49] Xu X, Boeckx P, Cleemput OV, Zhou L. Urease and nitrification inhibitors to reduce emissions of $\mathrm{CH}_{4}$ and $\mathrm{N}_{2} \mathrm{O}$ in rice production. Nutrient Cycling in Agroecosystems. 2002;64:203211. DOI: $10.1023 / \mathrm{A}: 1021188415246$

[50] Almeida RG, Gomes RC, Silva VP, Alves FV, Feijó GLD, Ferreira AD, Oliveira EB, Bungenstab DJ. Carbon Neutral Brazilian Beef: Testing Its Guidelines through a Case Study. Campo Grande: Embrapa Beef Cattle Doc No. 2016; 2016. 16 p

[51] Baligar VC, Fageria NK, He ZL. Nutrient use efficiency in plants. Communication in Soil Science and Plant Analysis. 2001;32:921-950 
[52] Fageria NK, Morais OP, Santos AB. Nitrogen use efficiency in upland rice genotypes. Journal of Plant Nutrition. 2010;33:1696-1711. DOI: 10.1080/01904167.2010.496892

[53] Gerloff GC, Gabelman WH. Genetic basis of inorganic plant nutrition. In: Lauchli A, Bieleski RL, editors. Inorganic Plant Nutrition. Encyclopedia and Plant Physiology New Series. 15th ed. New York: Springer Verlag; 1983. pp. 453-480

[54] Raun WR, Johnson GV. Improving nitrogen use efficiency for cereal production. Agronomy Journal. 1999;91:357-363 